\title{
ANALISIS FAKTOR-FAKTOR YANG BERHUBUNGAN DENGAN PELAKSANAAN KOMUNIKASI TERAPEUTIK PERAWAT DI IPCU RSJ Dr. RADJIMAN WEDIODININGRAT LAWANG
}

\author{
Adi Suyitno, Titin Andri Wihastuti, Lilik Supriati \\ Program Studi Magister Keperawatan Fakultas Kedokteran Universitas Brawijaya \\ Jl. Veteran Malang JawaTimur \\ E-mail : adisuyitnos@yahoo.co.id
}

\begin{abstract}
The nurse is the primary healthcare provider in the hospital and has an important role in the health service for the patient. Patients who come to the Intensive Psychiatric Care Unit (IPCU) generally exhibit various symptoms of behavioral problems, such as violent behavior, other injurious tendencies, agitation, and attempted suicide, requires the nurse to make a strict 24-hour observation. The aims of this research was to analyze various factors that have associated with implementation of therapeutic communication in IPCU RSJ Dr.RadjimanWediodiningratLawang. This research was an analytic observational research with cross sectional approach. Population in this research is all of IPCU nurses (Camar, Perkutut and mawar ward) 43 respondent. The number of samples is 40 respondents. To know the description of each variable used univariate analysis, to know the relationship between variables used Spearman test when the data is normally distributed and spearman and to know the most dominant factor in affecting implementation of therapeutic communication is used multivariate test of linear regression. The result of bivariate test shows $p$ value as follows: nurse knowledge level $(p=0,004)$, nurse perception $(p=0,123)$, nurse emotional intelligence $(p=0,015)$, nurse age $(p=0,227)$, Nurse education $(p=0,351)$, if this value has been lower than 0,05 then this variabel has significan relations with dependenvariabel. The results of multivariate test has shown that knowledge level has becae a most influence factors that affect the implementation of therapeutic communication. There was a significant correlation between nurse emotional intelegence and levels of knowledge with implementation of therapeutic communication in IPCU RSJ Dr.Radjiman Wediodiningrat Lawang
\end{abstract}

Keyword : knowledge, perception, emotional intelligence, age, education, implementation of therapeutic communication

Abstrak : Perawat merupakan tenaga kesehatan utama di rumah sakit dan memiliki peranan penting
dalam pelayanan kesehatan kepada pasien. Pasien yang datang di Intensive Psychiatric Care Unit
(IPCU) umumnya menunjukkan berbagai gejala masalah perilaku, seperti perilaku kekerasan,
kecenderungan mencederai orang lain, agitasi, dan percobaan bunuh diri sehingga menuntut perawat
untuk melakukan observasi ketat selama 24 jam. Melakukan analisis faktor internal yang berhubungan
dengan pelaksanaan komunikasi terapeutik perawat di IPCU RSJ Dr. Radjiman Wediodiningrat
Lawang. Penelitian ini observasion alanalitik dengan pendekatan cross sectional. Populasi dalam
penelitian ini adalah semua perawat IPCU (Ruang Camar, Perkutut dan Mawar) yang berjumlah 43
orang dengan jumlah sampel 40 orang. Untuk mengetahui hubungan antar variabel digunakan uji
spearman dan untuk mengetahui faktor yang paling dominan dengan pelaksanaan komunikasi
terapeutik digunakan uji multivariate regresi linier. Hasil uji bivariat menunjukkan $p$ value sebagai
berikut : tingkat pengetahuan perawat ( $p=0,004$ ), persepsi perawat $(p=0,123)$, kecerdasan emosi
perawat ( $p=0,015)$, usiaperawat ( $p=0,227)$, pendidikan perawat ( $\mathrm{p}=0,351)$, dimana hubungan
dikatakan bermakna apabila $p<0,05$. analisis multivariat dengan regresi linier diperoleh hasil bahwa
tingkat pengetahuan merupakan faktor yang paling dominan dengan nilai $p(0,004)$ dengan nilai $r=$
0,300 yang artinya variable ini memiliki keeratan hubungan yang sedang. Terdapat hubungan yang
bermakna antara pengetahuan dan kecerdasan emosi perawat dengan pelaksanaan komunikasi
terapeutik pada perawat di IPCU RSJ Dr. Radjiman Wediodiningrat Lawang.

Kata Kunci : pengetahuan, persepsi, kecerdasan emosi, usia, pendidikan perawat, pelaksanaan komunikasi terapeutik 


\section{PENDAHULUAN}

Perawat merupakan tenaga kesehatan utama di rumah sakit dan memiliki peranan penting dalam pelayanan kesehatan kepada pasien. Pasien yang datang di Intensive Psychiatric Care Unit (IPCU) umumnya menunjukkan berbagai gejala masalah perilaku, seperti perilaku kekerasan, kecenderungan mencederai orang lain, agitasi, dan percobaan bunuh diri. Kondisi pasien yang demikian menuntut perawat untuk melakukan observasi ketat selama 24 jam (Winkler at al., 2010) serta selalu menghadirkan dirinya dalam konteks terapeutik melalui interaksi komunikasi dengan pasien (Stuart \& Laraia, 2013). Rutinitas, keadaan pasien yang dihadapi dan stress beban kerja tersebut dapat menjadikan stressor tersendiri bagi perawat (Wang et al., 2014; Yang, Meredith \& Khan, 2015), sehingga akan mempengaruhi komunikasi terapeutik perawat yang mengakibatkan perawat cenderung emosi sehingga mudah terpancing dengan kondisi pasien marah, membentak dan tidak terapeutik. Berdasarkan penelitian yang dilakukan oleh Acker (2012) terhadap 460 perawat jiwa di Amerika Serikat bahwa 56\% diantaranya mengalami kelelahan emosi, dan $73 \%$ mengalami stress pada level sedang, dimana kelelahan mental umumnya akan mengalami masalah emosional, dan masalah persepsi sehingga akan berpengaruh terhadap komunikasi terapeutik perawat dengan pasien (Fuente et al., 2014).

Fenomena yang terjadi adalah minimnya perawat yang melakukan komunikasi terapeutik, dimana pada tahun 2002 tindakan komunikasi terapeutik hanya mencapai 19,2\%, (Gusnilawati, 2012). Hal ini senada dengan yang disampaikan oleh Hammer (2014) dalam penelitiannya bahwa masih rendahnya perawat jiwa yang menggunakan komunikasi terapeutik sebagai sarana komunikasi serta menggali informasi dengan pasien jiwa. Penelitian lain terkait dengan komunikasi terapeutik juga dilakukan di Rumah Sakit Jiwa Daerah dr. Amino Gondhohutomo Semarang tahun 2008, dimana dalam penelitian tersebut didapati hasil perawat yang mempunyai komunikasi interpersonal tinggi sebanyak $56 \%$, sedangkan perawat yang mempunyai komunikasi interpersonal rendah sebanyak
$44 \%$, hal ini membuktikan bahwa komunikasi terapeutik yang rendah bisa dikarenakan perawat tidak memahami fungsi dari komunikasi terapeutik tersebut (Kamaldeep, 2015).

\section{METODE}

Penelitian ini merupakan penelitian observasionalanalitik. Penelitian ini mempelajari terkait dengan determinant dari faktor-faktor yang berhubungan dengan kejadian dan masalah yang berkaitan dengan kesehatan. Penelitian kali ini peneliti menggunakan pendekatan study cross sectional. (Sastroasmoro \& Ismael, 2011).

Pengumpulan data diambil pada bulan Mei 2017 dan penelitian ini dilaksanakan di IPCU RSJ Dr.Radjiman Wediodiningrat Lawang. Populasi dalam penelitian ini adalah semua perawat IPCU (Ruang Camar, Perkutut dan Mawar) RSJ Dr. Radjiman Wediodiningrat Lawang yang berjumlah 43 orang. Sampel dalam penelitian ini adalah sebagian perawat di IPCU RSJ Dr. Radjiman Wediodiningrat Lawang, meliputi perawat Ruang Camar, Perkutut dan Mawar yang memenuhi kriteria.

Kriteria inklusi dalam penelitian ini adalah : perawat IPCU yang bersedia menjadi responden penelitian dengan bukti informed consent. Sedangkan kriteria eksklusi dalam penelitian ini adalah: perawat IPCU yang sakit saat penelitian dilaksanakan.

\section{HASIL PENELITIAN}

\section{Distribusi Karakteristik Responden}

Berdasarkan olah data penelitian yang telah diperoleh bahwa rata-rata usia responden adalah 39.13 tahun yang termasuk dalam kategori usia dewasa pertengahan. Sedangkan rata-rata lama kerja responden di ruang IPCU RSJ Dr. Radjiman Wediodiningrat Lawang adalah 2,9 tahun. Selainitu, didapatkan bahwa sebagian besar jenis kelamin responden laki-laki yaitu 26 orang responden (65\%), status perkawinan responden sebagian besar responden telah menikah yaitu sebanyak 38 orang responden (95\%), berdasarkan jenis kepegawaian responden sebagian besar responden berstatus pegawai negeri sipil 
yaitu sebanyak 37 orang responden $(92,5 \%)$, dan berdasarkan tingkat pendidikan sebagian besar responden berpendidikan D IV Keperawatan kebawah yaitu sebanyak 31 orang responden $(77,5 \%)$.

\section{Analisis Bivariat}

Analisa bivariat dilakukan untuk mengetahui hubungan antara variable independen dengan variabel dependen. Dalam penelitian ini analisis bivariat yang akan digunakan adalah uji spearman.

Tabel 1. Hasil Analisis Bivariat

\begin{tabular}{cccc}
\hline \multirow{2}{*}{$\begin{array}{c}\text { Variabel } \\
\text { dependen }\end{array}$} & Variabel independen & P value & Pearson correlation \\
\hline \multirow{3}{*}{$\begin{array}{c}\text { Pelaksanaan } \\
\text { komunikasi terapeutik }\end{array}$} & Pengetahuan & 0.004 & 0,747 \\
\cline { 2 - 4 } & Kecerdasan Emosional & 0.123 & 0,693 \\
\cline { 2 - 4 } & Usia & 0.015 & 0,462 \\
\cline { 2 - 4 } & Pendidikan & 0.227 & $-0,128$ \\
\hline & & & $-0,003$ \\
\hline
\end{tabular}

Berdasarkan data diatas didapatkan bahwa variabel yang memiliki hubungan adalah variable kecerdasan emosi dan pengetahuan.

\section{PEMBAHASAN}

\section{a. Hubungan pengetahuan dengan pelaksanaan komunikasi terapeutik}

Berdasarkan hasil analisis dengan menggunakan korelasi Rank Spearman, didapatkan nilai $p$ value lebih kecil dari 0.05 (0.004) maka dapat disimpulkan bahwa terdapat hubungan antara tingkat pengetahuan dengan pelaksanaan komunikasi terapeutik perawat di ruang IPCU RSJ Dr. Radjiman Wediodiningrat Lawang, sehingga dengan semakin tingginya tingkat pengetahuan perawat maka akan berpengaruh terhadap pelaksanaan komunikasi terapeutiknya, begitu juga sebaliknya jika semakin rendah tingkat pengetahuan perawat maka pelaksanaan komunikasi terapeutiknya juga akan berdampak. Hal ini sesuai dengan penelitian yang dilakukan oleh Toni et al (2016) dimana dalam penelitiannya dijelaskan bahwa jenis kelamin, usia dan bahasa serta pengetahuan merupakan hal yang dapat mengimprovisasi performa komunikasi seseorang.

\section{b. Hubungan persepsi dengan pelaksanaan komunikasi terapeutik}

Hasil uji bivariate menggunakan korelasi Rank Spearman, didapatkan nilai $\mathrm{p}$ value lebih besar dari 0.05 (0.123) dimana hal ini menunjukkan bahwa variabel persepsi tidak memiliki kemaknaan secara statistika. Perbedaan hasil penelitian ini seperti yang diungkapkan oleh Zayyat (2014) dimana dalam penelitiannya didapatkan hasil bahwa persepsi seseorang dipengaruhi oleh tingkat stressor, jenis stressor dan strategi dalam koping, hal ini tentu akan mempengaruhi bagaimana pelaksanaan komunikasi terapeutik seseorang.

\section{c. Hubungan kecerdasan emosi dengan pelaksanaan komunikasi terapeutik}

Berdasarkan hasil analisis dengan menggunakan korelasi Rank Spearman, didapatkan nilai $p$ value lebih kecil dari 0.05 (0.015). Hasil ini memiliki kemaknaan secara statistik. Kecerdasan emosi adalah kemampuan seseorang mengatur kehidupan emosinya dengan intelegensi (to manage our emotional life with intelligence); menjaga keselarasan emosi dan pengungkapannya (the appropriateness of emotion and its expression) melalui keterampilan kesadaran diri, pengendalian diri, motivasi diri, empati dan keterampilan soasial (Goleman, 2002). Hasil penelitian tingkat kecerdasan emosi perawat di IPCU RSJ Dr. Radjiman Wediodiningrat Lawang menunjukkan bahwa sebagian besar perawat memiliki tingkat kecerdasan emosi cukup yaitu sejumlah 35 orang responden $(87,5 \%)$ 


\section{d. Hubungan usia dengan pelaksanaan komunikasi terapeutik \\ Berdasarkan hasil analisis dengan} menggunakan korelasi Rank Spearman, didapatkan nilai $\mathrm{p}$ value lebih besar dari 0.05 (0.227). Hasil ini secara statistik tidak memiliki hubungan yang bermakna. Dari hasil penelitian ini diperoleh data bahwa responden memiliki usia rata-rata 39,13 tahun yang berjumlah 19 responden (47.5\%). Hasil penelitian ini sejalan dengan penelitian Dedah (2001), Hasan (2002), dan Edyana (2008) yang menyatakan bahwa pada karakteristik perawat rentang usia perawat berada pada rentang usia dewasa pertengahan.

\section{e. Hubungan pendidikan dengan pelaksanaan komunikasi terapeutik}

Hasil analisis bivariat diketahui bahwa nilai $P$ value riwayat pendidikan $0,351 \quad(p>0,05)$ terhadap kemampuan komunikasi perawat yang berarti tidak memilikihubungan yang bermakna secara statistik terhadap kemampuan komunikasi perawat dalam pelaksanaan komunikasi terapeutik.

Hasil penelitian ini menyebutkan bahwa sebagian besar perawat merupakan perawat lulusan Diploma IV (D-IV) keperawatan kebawah yaitu sebanyak 31 responden (77.5\%). Dengan hasil ini disimpulkan bahwa sebagian besar responden memiliki pengalaman mengecap pendidikan tinggi dengan asumsi bahwa pengetahuan dan ketrampilan yang dimilikinya akan tinggi pula. $\mathrm{Hal}$ ini sebagaimana telah diungkapkan Siagian (2001) dalam Edyana (2008) bahwa proses pendidikan merupakan pengalaman yang berfungsi mengembangkan kemampuan dan kualitas kepribadian seseorang, dimana semakin tinggi tingkat pendidikan maka akan semakin besar motivasinya untuk memanfaatkan pengetahuan dan ketrampilannya.

\section{DAFTAR PUSTAKA}

Agustian, A. G. (2007). Rahasia Sukses Membangun Kecerdasan emosi dan spiritual ESQ: Emotional Spiritual Quotient Berdasarkan 6 rukun Iman dan 5 Rukun Islam. ARGA Publishing, Jakarta.

\section{f. Faktor yang paling dominan yang mempengaruhi komunikasi terapeutik}

Berdasarkan hasil analisis multi variate regresi linier bahwa variable dominan yang paling berhubungan dengan pelaksanaan komunikasi terapeutik perawat di IPCU RSJ Dr. Radjiman Wediodiningrat Lawang adalah faktor pengetahuan dengan $p$ value 0,004 dengan nilai $r$ adalah 0,300 dimana nilai ini menunjukkan bahwa tingkat pengetahuan perawat memiliki pengaruh yang besar bagaimana perawat mampu melakukan komunikasi terapeutik dengan baik.

\section{IMPLIKASI HASIL PENELITIAN}

Dari hasil penelitian ini didapatkan gambaran tentang factor yang berhubungan dengan pelaksanaan komunikasi terapeutik, dimana pengetahuan dan kecerdasan emosi berkontribusi terhadap pelaksanaan komunikasi terapeutik, manfaat yang didapatkan dari hasil penelitian ini adalah bahwa dengan peningkatan pengetahuan maka akan meningkatkan juga komunikasi terapeutik perawat sehingga perlu adanya pengembangan keterampilan dan panduanpanduan I SOP dalam pelaksanaan komunikasi terapeutik tersebut.

Penelitian ini memberikan output berupa data awal tentang faktor-faktor yang berhubungan dengan pelaksanaan komunikasi terapeutik perawat untuk dapat meningkatkan kualitas pelayanan serta strategi yang dapat digunakan sebagai dasar pengembangan kualitas.

\section{KESIMPULAN}

Faktor yang berhubungan dengan pelaksanaan komunikasi terapeutik adalah factor pengetahuan dan kecerdasan emosi perawat.
Arikunto, S. (2006). Penelitian suatu Pendekatan Praktek. Jakarta: Rineka Cipta.

Azmiani, dkk. (2012). Makalah Psikologi Sosial remaja dan Pacaran. Fakultas Psikologi, Universitas Islam Sultan agung, Semarang. 
Bogaert, P. V., et al. (2013). The Relationship Between Nurse Practice Environment, Nurse Work Characteristics, Burnout and Job Outcome and Quality of Nursing Care: A Cross-Sectional Survey. International Journal of Nursing Studies. 50 (1).

Departemen Kesehatan RI. (2008). Riset Kesehatan dasar (RISKESDAS) 2007. Jakarta; Badan Penelitian dan Pengembangan Kesehatan Departemen Kesehatan, Republik Indonesia.

Fuente, et al. (2014). Risk Factors and Prevalence of Burnout Syndrome in the Nursing Profession. International Journal of Nursing Studies. 52 (1)

George, et al. (2012). Emotional Intelligence and Job Satisfaction: A Correlations Study: The International Journal's.

Goleman, D. (2000). Emotional Intelligence: Mengapa El Lebih Penting Daripada IQ. Jakarta: Gramedia Pustaka ulama.

Goleman, D. (2002). Healing Emotions: Percakapan dengan Dalai Lama, tentang Mediasi, Perasaan dan Kesehatan. Batam; Interaksara.

Goleman, D. (2005). Kecerdasan Emosi untuk Mencapai Puncak Prestasi. Jakarta: Gramedia Pustaka Utama.

Goleman, D. (2006). Emotional Intligence. Jakarta; Gramedia Pustaka Utama.

Hall, J. E. (2007). Buku Saku Fisiologi Kedokteran, Edisi 11. Jakarta: Penerbit Buku Kedokteran EGC.

Hawari, D. (2006). Pendekatan Holistik Pada Gangguan Jiwa Skizofrenia. Jakarta; FKUI.

Hidayat, A. Aziz Alimul. (2007). Metode Penelitian Keperawatan dan Teknik Analisis Data. Jakarta: Salemba Medika.

Kamaldeep, et al. (2015). Interventions to improve Therapeutic Communications Between Black and Minority Ethnic Patients and Professionals in Psichiatric Services: Systematic Review. The British Journal of Psychiatry.
Karimi, et al. (2013) Emotional Resive: The Role of Emotional Intelligence and Emotional Labour on Well Being and Job-Stress Among Community Nurses. Journal of Advanced Nursing.

Kariyoso. (1994). Pengantar Komunikasi bagi Siswa Perawat, Jakarta: Buku Kedokteran EGC.

Keliat, Budi Anna. (1992). Hubungan Terapeutik Perawat-Klien. Jakarta: Buku Penerbit Kedokteran EGC.

Liyana. (2010). Pengaruh Komunikasi Terapeutik Perawat Terhadap Kepuasan Pasien Di Ruang Rawat Inap RS THT dan Bedah Prof. Nizar Jakarta Pusat. Skripsi. Universitas Indonesia esa Unggul Fakultas IImu Kesehatan Jurusan Keperawatan, Jakarta.

Madathil, R., Heck, N. C., \& Schuldberg, B. (2014). Burnout in Psychiatric Nursing: Examining the Interplay of Autonomy, Leadership Style and Depressive Symptoms. Archives of psychiatric Nursing. 28 (1).

Martin, A. D. (2006). Smart Emotional Volume 1 Membangun Kecerdasan Emosi. Jakarta: PT, Gramedia Pustaka Utama.

Mulyani, Sri. (2008). Analisis Pengaruh factor-Faktor Kecerdasan Emosi Terhadap Komunikasi Interpersonal Perawat Dengan Pasien Di Unit Rawat Inap RSJ. Dr. amino Gondohutomo Semarang. Skripsi. Program Studi Magister Ilmu Kesehatan Masyarakat Konsentrasi Administrasi Rumah Sakit, Semarang.

Mundakir. (2006). Komunikasi Keperawatan Aplikasi Dalam Pelayanan. Yogyakarta: Graha ilmu.

Notoatmodjo, S. (2001). Pengantar Pendidikan Kesehatan dan IImu Perilaku Kesehatan, andi Offset, Yogyakarta.

Potter \& Perry. (2002). Buku Ajar Fundamental Keperawatan Konsep, Proses dan Praktik. Jakarta: Buku Penerbit Kedokteran EGC.

Santrock. (2007). Remaja, edisi 11, Erlangga, Jakarta. 
Sawaf, Ayman. RK, Cooper. (2001). Executive EQ: Kecerdasan Emosional dalam Kepemimpinan dan Organisasi. Jakarta; Gramedia Pustaka Utama.

Shapiro, LE. (2003). Mengajarkan Emotional Intelligence Pada Anak. Jakarta: PT Gramedia Pustaka Utama.

Sugiyono, (2010). Metode Penelitian Pendidikan Pendekatan Kuantitatif, Kualitatif dan $R$ \& $D$. Bandung: Alfabeta.

Snowden, et al. (2015). The Relationship Between Emotional Intelligence, Previous Cring Experience and Mind fullness in Student Nurses and Mind Fulness in Student Nurses and Midwives: a Cross Sectional Analysis. International Journal of Nursing Studies.

Stuart, GW. (2007). Buku Saku Keperawatan Jiwa. Edisi 5. Jakarta: Penerbit Buku Kedokteran EGC.
Stuart \& Sundeen, (2006). Buku Saku Keperawatan Jiwa. Jakarta: Buku Penerbit Kedokteran EGC.

Stuart, G. W., \& Laraia, M. T. (2013). Principles and Practice of Psychyatric Nursing-10 $10^{\text {th }}$ ed. United States of Amerika: Mosby Elsevier.

Videbeck, L. Sheila. (2008). Buku Ajar Keperawatan Jiwa. Jakarta: Buku Penerbit Kedokteran EGC.

Wang, et al. (2014). The Relationship Among Work Stress, Resourcefulness and Depression Level in Psychyatric Nurses. Archives of Psychyatric Nursing. 29 (1)

Winkler, et al. (2010). Intensive Care in Psychiatry. European Psychiatry. (26) 